\title{
PENGEMBANGAN DOMINO PECAHAN BERBASIS OPEN ENDED UNTUK MENINGKATKAN KEMAMPUAN BERPIKIR KREATIF SISWA SD
}

\author{
Mohammad Faizal Amir ${ }^{1)}$, Mahardika Darmawan Kusuma Wardana ${ }^{2)}$ \\ ${ }^{1), 2)}$ PGSD FKIP Universitas Muhammadiyah Sidoarjo \\ E-mail: faizal.amir@umsida.ac.id ${ }^{l}$ \\ mahardikadarmawan umsida.ac.id ${ }^{2)}$
}

\begin{abstract}
This research aims to develop an open ended domica-based cards in improving creative thinking ability of elementary school students on the material fractions and find out the results of its development. The development was done by using Plomp model which consists of: (1) the initial Investigation, (2) design, (3) the realization/construction, (4) the testing, evaluation, and revision, (5) implementation. The research subjects at the the testing, evaluation, and revision phase is 38 6th grade students of SDN Kenongo 1 Tulangan Sidoarjo. While in the implementation phase, the ubject is 40 6th grade students SDN Kalitengah 1 Tanggulangin Sidoarjo. Data collection techniques use creative thinking tests, observation of students' creative thinking activities, questionnaires, and documentations. The results concluded that the open ended domica-based card to enhance the creativity of elementary school students produced two sets of cards in the material of common fraction and mixed fractions, as well as a set of cards consisting of whole fractions sub material (regular, percent, and decimal fractions), each of which contains 66 cards. Domica-based card open ended trial results good quality because it has met the criteria of validity, practicality, and effectiveness to train the creativity of students in the aspect of flexibility, elaboration, and novelty.
\end{abstract}

Keywords: Card, Domica, Open Ended, Creativity

\section{PENDAHULUAN}

Kualitas perkembangan ilmu pengetahuan dan teknologi saat ini selayaknya didukung dengan kemampuan mencipta hal-hal yang baru dan kemampuan dalam menggunakannya, agar ilmu pengetahuan dan teknologi senantiasa berkembang, untuk itu diperlukan kemampuan berpikir kreatif yang juga merupakan tingkat berpikir paling tinggi. Sebagaimana pendapat Apino dan Retnawati (2017) yang menyatakan bahwa berpikir kreatif merupakan tingkat berpikir tertinggi setelah mengingat, berpikir dasar, dan berpikir kritis.

Untuk memperoleh dan mencetak seseorang agar memiliki tingkat kemampuan berpikir tertinggi, lazimnya adalah melalui proses pendidikan yang baik. Artinya semua rumpun keilmuan termasuk pendidikan matematika harus dapat mencetak siswa yang dapat memiliki kemampuan berpikir kreatif.

Pemerintah Indonesia memberikan amanah kepada guru-guru, agar siswa-siswanya dapat memiliki kemampuan berpikir kreatif. Sebagaimana pada salinan 
Permendiknas No. 20 tahun 2016 bahwa melalui pendekatan ilmiah suatu pembelajaran termasuk pada mata pelajaran matematika, siswa diharapkan memiliki kemampuan berpikir dan bertindak secara kreatif, produktif, kritis, mandiri, kolaboratif, dan komunikatif (BNSP, 2016).

Namun seringkali dalam pembelajaran matematika, kreativitas siswa bukan menjadi prioritas utama guru karena seringkali guru hanya memberikan soal-soal dan menekankan pada aspek kebenaran jawaban tanpa menekankan pada aspek-aspek kreativitas. Seperti pendapat Siswono (2008) berpikir kreatif jarang ditekankan pada pembelajaran matematika karena pembelajaran yang diterapkan cenderung berorientasi pada pengembangan pemikiran analitis dengan masalah-masalah yang rutin.

Pendidikan sekolah dasar merupakan pondasi utama untuk menanamkan sekaligus mengembangkan kemampuan berpikir kreatif siswa, oleh sebab itu seharusnya sekolah-sekolah di Sekolah Dasar (SD) harus menyiapkan dan mencetak siswa agar menjadi pemikir kreatif yang siap bersaing pada jenjang pendidikan berikutnya serta memiliki bekal yang dapat digunakan bagi kehidupannya kelak.

Pada Kurikulum 2006 dan Kurikulum 2013 yang berlaku di Indonesia saat ini terdapat materi pecahan, menurut Mahmudi (2009) pecahan merupakan konsep yang relatif sulit dan menantang bagi siswa. Selain itu kreativitas siswa SD dalam menyelesaikan soal-soal pecahan masih tergolong rendah. Hasil penelitian Ristiani (2014) menyatakan tingkat berpikir kreatif siswa sekolah dasar pada materi pecahan adalah $60 \%$ tidak kreatif, 30\% kurang kreatif, 10\% cukup kreatif, $0 \%$ atau tidak ada siswa yang termasuk kategori kreatif dan sangat kreatif. Oleh karena itu, kreativitas siswa dalam menyelesaikan soal pecahan merupakan masalah yang harus dicarikan solusi.

Guru sebagai pelopor utama pendidikan memiliki kewajiban meningkatkan kualitas proses pembelajaran dan sekaligus menyelesaikan masalah-masalah yang ada dalam pembelajaran, Sanjaya (2013) menyatakan salah satu keterampilan yang harus dimiliki guru dalam kelas adalah variasi stimulus dalam penggunaan media pembelajaran. Variasi ini diperlukan agar menjaga iklim pembelajaran tetap kondusif dan agar proses penyampaian pesan materi pelajaran oleh guru berjalan efektif.

Bagi siswa yang berada pada tahap pra operasional dan operasi kongkret, belajar sambil bermain memungkinkan mereka menemukan konsep-konsep atau generalisasi matematika (Sitanggang, 2013). Sehingga, siswa Sekolah Dasar yang berada pada kisaran tahap operasi kongkret, selain membutuhkan media sebagai alat bantu, mereka juga membutuhkan suatu wadah aktivitas berupa permainan dalam pembelajaran. Kristiyono (2008) metode permainan kartu yang merupakan pengembangan media kreatif berupa kartu domino dapat menjadi strategi meningkatkan kemahiran siswa dalam bilanganbilangan dasar.

Media berupa kartu domica (domino pecahan) dapat menjadi solusi permasalahan, kartu domica ini dikembangkan menjadi kartu berbasis open ended. Vale, dkk (2012) pemberian tugas berpola open ended memberikan kesempatan siswa untuk menggali potensi kreatif dengan menghubungkan berbagai topik matematika. Mahmudi (2009) pengembangan kemampuan berpikir 
kreatif siswa dapat dilakukan dengan menggunakan soal-soal open ended.

Berdasarkan uraian-uraian di atas diperlukan pengembangan suatu media kartu domica berbasis open ended yang baik atau berkualitas agar dapat digunakan siswa belajar sekaligus bermain sehingga dapat meningkatkan kemampuan berpikir kreatif siswa Sekolah Dasar pada materi pecahan.

\section{METODE PENELITIAN}

Jenis penelitian ini merupakan penelitian pengembangan menggunakan model pengembangan Plomp (1997) yang terdiri dari: (1) Investigasi awal, (2) Desain, (3) Realisasi/konstruksi, (4) Tes, Evaluasi, dan Revisi, (5) Implementasi. Penelitian ini dilakukan pada bulan Juni-September 2017.

Pada fase investigasi awal dilakukan analisis kurikulum, analisis siswa, analisis materi ajar, dan analisis tuntutan kurikulum. Berdasarkan hasil analisis dari fase investigasi awal, selanjutnya menuju pada fase desain untuk dilakukan analisistentang rancangan kartu domica berbasis open ended yang dikembangkan. Analisis tersebutmeliputi analisis penyusunan kartu domica dan instrumen penelitian.

Pada fase realisasi/konstruksi dilakukan finalisasi rancangan kartu domica dan instrumen, hasil dari fase ini disebut dengan Prototipe I. Fase tes, evaluasi, dan revisi dilakukan dengan validasi kartu domica dan instrumen penelitian, serta ujicoba kartu domica. Pada fase ini dilakukan validasi oleh 3 validator, validasi berupa pertimbangan dan saran ahli terhadap kartu domica digunakan sebagai dasar untuk melakukan revisi, hasil revisi kartu disebut Prototipe II yang selanjutnya dilakukan ujicoba di kelas VI SDN Kenongo 1 Tulangan Sidoarjo tahun ajaran 2017-2018 yang terdiri dari 38 siswa.
Setelah menghasilkan prototipe final, kartu domica diterapkan dalam ruang lingkup sekolah yang lain. Penerapan ini dilakukan di kelas VI SDN Kalitengah 1 Tanggulangin Sidoarjo Tahun Ajaran 2017/2018 yang terdiri dari 40 siswa. Dalam pelaksanaan uji coba dan implementasi kartu domica masing-masing dilakukan pengamatan aktivitas berpikir kreatif siswa saat menggunakan kartu domica selama 3 kali pertemuan. Pada akhir pertemuan diberikan Tes Kemampuan Berpikir Kreatif Siswa (TBK) dan angket respon siswa terhadap kartu domica.

Kartu domica berbasis open ended dikembangkan berdasarkan perspektif prototipe produk berkualitas menurut Nieven (1999) bahwa kualitas prototipe suatu produk dinilai dari kevalidan, kepraktisan, dan keefektifan

Validasi desain produk dalam research and development (penelitian dan pengembangan) dapat dilakukan melalui validasi oleh ahli (Sugiyono, 2013). Kriteria kevalidan kartu domica dan instrumen penelitian dilakukan dengan mengkonversi Rata-rata Total Validitas (RTV) dari penilaian ahli, pada kategori kevalidan menurut Khabibah (2006) yakni $4 \leq R T V \leq 5$ : sangat valid, $3 \leq R T V<4$ : valid, $2 \leq$ $R T V<3$ : kurang valid, $1 \leq R T V<2$ : tidak valid.

Produk dikatakan praktis jika secara teoritis para ahli menyatakan bahwa produk dan pelaksanaan pembelajaran yang menjadi fokus penelitian dalam kategori "baik" sesuai dengan karakteristik penelitian masingmasing (Rohmad, 2012). Kartu Domica dikatakan praktis jika secara teori validator menyatakan bahwa kartu domica dapat digunakan dengan revisi kecil atau tanpa revisi, yang telah diisi pada lembar validasi. Berkaitan dengan fokus penelitian yakni aktivitas berpikir 
kreatif siswa dalam menggunakan kartu domica, kepraktisan kartu domica melalui hasil pengamatan apabila minimal $60 \%$ siswa melakukan aktivitas berpikir kreatif.

Rohmad (2012) menjelaskan keefektivan suatu produk pembelajaran dapat dilihat dari sejauh mana tingkat prestasi belajar siswa setelah menggunakan produk dan keinginan siswa untuk menggunakan produk tersebut di kemudian hari. Oleh karena itu, keefektivan suatu produk dapat dilihat dari hasil belajar dan respon siswa. Kartu domica yang dikembangkan dikatakan efektif jika perolehan respon siswa termasuk kategori positif. Analisis respon siswa dihitung melalui skala sikap yang digunakan untuk mengukur kecenderungan sikap dan perilaku siswa terhadap pernyataan yang diajukan. Siswa memberikan nilai dengan rentang nilai sangat setuju (SS), setuju (S), tidak setuju (TS), dan sangat tidak setuju (STS). Angket respon siswa terdiri dari dua jenis pernyataan, yaitu pernyataan positif (favorable) dan pernyataan negatif (unfavorable). Kemudian membuat kategori untuk seluruh butir pernyataan yaitu: (1) Jika $\geq 50 \%$ dari seluruh butir pernyataan termasuk dalam kategori sangat kuat atau kuat maka respon siswa dikatakan positif. (2) Jika $<50 \%$ dari seluruh butir pernyataan termasuk dalam kategori sangat kuat atau kuat maka respon siswa dikatakan negatif. Berkaitan dengan hasil kemampuan berpikir kreatif siswa, apabila siswa mencapai ketuntasan belajar cukup kreatif dengan ketentuan secara klasikal lebih besar atau sama dengan $70 \%$, maka kartu domica dikatakan efektif.

Instrumen penelitian meliputi: (1) lembar validasi, (2) lembar observasi penggunaan kartu domica, (3) lembar Tes Kemampuan Berpikir Kreatif
(TBK) Siswa, dan (4) lembar respons siswa. Sedangkan teknik pengumpulan data meliputi 1) Observasi aktivitas berpikir kreatif siswa selama bermain kartu domica menggunakan, 2) Dokumentasi selama pembelajaran berlansung. 3) Pemberian Tes Berpikir Kreatif (TBK) dan kuesioner angket saat akhir pelaksanaan fase ujicoba dan implementasi.

\section{HASIL PENELITIAN DAN PEMBAHASAN Fase Investigasi Awal}

Pada fase ini dilakukan analisis kurikulum, analisis siswa, analisis materi ajar, dan analisis tuntutan kurikulum. Kurikulum yang digunakan pada kelas VI di SDN Kenongo 1 Tulangan dan SDN Kalitengah 1 Tanggulangin adalah Kurikulum 2006. Sedangkan tuntutan kurikulum tersebutpada pembelajaran matematika adalah siswa harus dibekali dengan kemampuan berpikir logis, analitis, sistematis, kritis, dan kreatif, termasuk kemampuan bekerjasama.

Hasil dari analisis materi dan siswa antara lain 1) Siswa sudah mengenal dan mempelajari materi bentuk-bentuk pecahan senilai (biasa, campuran, persen, dan desimal). 2) Siswa yang diteliti memiliki kemampuan beragam. 3) Siswa belum pernah diajarkan pembelajaran matematika yang menekankan pada kemampuan berpikir kreatif. 4) Kemampuan berpikir terutama kemampuan berpikir kreatif siswa dapat dilatihkan, terutama mulai usia sekolah dasar. 5) Siswa cenderung membutuhkan permainan dan media dalam melatih kompetensi pada materi matematika. 6) Siswa pada dasarnya memiliki kemampuan berpikir kreatif, namun tidak ada media pembelajaran yang dapat memfasilitasi siswa dalam melatih kompetensi pada materi 
pecahan yang dapat dilakukan sambil bermain. 7) Pembelajaran sudah berkelompok dan berdiskusi, namun guru masih mendominasi pembelajaran.

Hal utama yang menjadi masalahmasalah tersebut adalah ketidaktersediaan media yang dapat melatihkan kemampuan berpikir kreatif siswa pada materi bentuk-bentuk pecahan senilai (biasa, campuran, persen, dan desimal). Media yang dimaksud adalah kartu domica (domino pecahan) berbasis open ended.

\section{Fase Desain}

Analisis pada fase ini menghasilkan desain kartu domica yang terdiri dari 1 set kartu materi pecahan biasa, 1 set kartu kartu materi pecahan campuran, dan 1 set kartu berbagai bentuk pecahan (biasa, campuran, persen, desimal) beserta desain box dan aturan permainan. Selain itu dihasilkan draft instrumen penelitian yang meliputi lembar validasi, lembar observasi, Tes Berpikir Kreatif (TBK), dan angket respon siswa.

\section{Fase Realisasi/Konstruksi}

Pada fase ini dilakukan finalisasi rancangan kartu domica dan instrumen penelitian, hasil dari fase ini disebut dengan Prototipe I.

\section{Fase Tes, Evaluasi, dan Revisi (Ujicoba)}

Pelaksanaan fase ini dilakukan dengan dua tahap, yaitu validasi dan uji coba kartu. Kartu domica dan instrumen penelitian divalidasi oleh 3 validator. Berdasarkan analisis dan kriteria kevalidaan instrumen, menunjukkan kartu domica dalam kategori valid $(3,75)$. Sementara intrumen penelitian berupa lembar observasi sangat valid $(4,0)$, Tes Berpikir Kreatif (TBK) sangat valid $(3,875)$, angket respon sangat valid $(4,125)$. Ketiga validator menyatakan kartu domica dan instrumen dapat digunakan dengan revisi kecil, serta memberi saran terhadap kartu domica. Adapun secara umum saran dan komentar tersebut adalah 1) Satu soal kartu domica lebih baik terdiri dari 12 bilangan bertipe berbeda sehingga ada 66 kartu bukan 55 kartu agar siswa semakin banyak memiliki alternatif jawaban dan cara sehingga soal semakin open ended untuk dapat melatihkan kreativitas siswa, 2) Bentuk persen dan desimal tidak memungkinkan untuk dibuatkan soal open ended pada kartu domica, 3) Pada kartu berbagai bentuk pecahan terdiri dari materi pecahan biasa, persen, dan desimal, 4) Gunakan bahasa petunjuk permainan yang mudah dipahami untuk anak sekolah dasar.

Hasil revisi dari validator menghasilkan prototipe II kartu domica yang akan dikembangkan meliputi 3 set jenis terdiri dari masing-masing 1 set kartu jenis pecahan senilai dengan sub materi pecahan biasa dan pecahan campuran dan satu set kartu berbagai jenis pecahan (pecahan biasa, pecahan persen, dan pecahan desimal) untuk meningkatkan kemampuan berpikir kreatif siswa sekolah dasar. Satu set kartu tersebut masing-masing terdiri dari 66 kartu.

Uji coba kartu domica dan instrumen penelitian menggunakan prototipe II dilaksanakan dengan tujuan untuk menguji efektivitas penggunaan kartu domica Semua material Prototipe II baik kartu domica maupun instrumen penelitian diujicobakan pada 38 siswa kelas VI SD Negeri Kenongo 1 Tulangan, Sidoarjo.

Uji coba penggunaan kartu domica dan instrumen penelitian dilaksanakan selama 4 kali pertemuan di bulan Agustus. Pengamatan penggunaan kartu domica terhadap kreativitas siswa, diamati oleh dua 
orang pengamat. Satu kelompok terdiri dari 4 siswa, masing-masing kelompok diamati 2 pengamat untuk melihat aktivitas berpikir kreatif siswa dalam menggunakan kartu domica, hasil pengamatan uji coba selanjutnya dianalisis. Dalam penelitian ini kelompok yang diamati dibatasi hanya pada 2 kelompok. Pada tahap uji coba diperoleh data siswa tentang: 1) Aktivitas berpikir kreatif, 2) Kemampuan berpikir Kreatif, dan 3) Respon angket siswa. Hasil analisis data aktivitas berpikir kreatif siswa pada fase ujicoba disajikan pada Tabel 1.

Tabel 1 Hasil Analisis Data Aktivitas Berpikir Kreatif Siswa Pada Kartu Domica Berbasis Open Ended Fase Uji Coba

\begin{tabular}{|c|c|c|c|c|c|c|c|}
\hline \multirow[t]{2}{*}{$\begin{array}{l}\text { Aktivitas Berpikir } \\
\text { Kreatif no. }\end{array}$} & \multicolumn{2}{|c|}{$\begin{array}{l}\text { Rata-rata Frek. } \\
\text { Aktivitas pada } \\
\text { Kartu Domica } \\
\text { Pecahan Biasa } \\
\end{array}$} & \multicolumn{2}{|c|}{$\begin{array}{c}\text { Rata-rata Frek. } \\
\text { Aktivitas pada } \\
\text { Kartu Domica } \\
\text { Pecahan Campuran }\end{array}$} & \multicolumn{2}{|c|}{$\begin{array}{l}\text { Rata-rata Frek. } \\
\text { Aktivitas pada } \\
\text { Kartu Domica } \\
\text { Berbagai Pecahan } \\
\end{array}$} & \multirow[t]{2}{*}{ Total } \\
\hline & K1 & K2 & K1 & K2 & K1 & K2 & \\
\hline 1 & 13 & 11.5 & 11 & 13 & 12 & 14.5 & 75 \\
\hline 2 & 12.5 & 11 & 9.5 & 11 & 12.5 & 13.5 & 70 \\
\hline 3 & 6.5 & 8 & 7.5 & 8 & 6.5 & 5.5 & 42 \\
\hline 4 & 7.5 & 8.5 & 8 & 8 & 8 & 8.5 & 48.5 \\
\hline Total & 39.5 & 39 & 36 & 40 & 39 & 42 & 235.5 \\
\hline Rata-rata dalam \% & 70.54 & 69.64 & 64.29 & 71.43 & 69.64 & 75 & \\
\hline
\end{tabular}

Keterangan:

$\mathrm{K}_{1}=$ Rata-rata frekuensi kelompok1 oleh pengamat1 dan pengamat 2

$\mathrm{K}_{2}=$ Rata-rata frekuensi kelompok 2 oleh pengamat 3 dan pengamat 4

Aktivitas berpikir kreatif no:

1 = memberikan jawaban benar yang berbeda

2 = memberikan cara/strategi penyelesaian benar yang berbeda

3 = memberikan cara/strategi benar dan berbeda dari tingkat kognitif pada umumnya

4 = memberikan generalisasi konsep atau pola

Pada uraian sebelumnya diketahui kartu domica "dapat digunakan dengan revisi kecil "berdasarkan penilaian validator dan pada Tabel 1 diketahui rata-rata total aktivitas berpikir kreatif siswa sebesar 70,08\%. Sehingga dapat disimpulkan kartu domica praktis untuk digunakan meningkatkan kreativitas siswa sekolah dasar.

Aktivitas berpikir kreatif nomer 1 (kefasihan) paling tinggi diantara aktivitas berpikir kreatif lain setelah aktivitas berpikir kreatif berturut-turut aspek nomer 2 (fleksibilitas), aspek nomer 4 (elaborasi), aspek nomer 2 (kebaharuan). Hal ini menunjukkan kartu domica cenderung melatihkan aktivitas berpikir kreatif dalam aspek fluency (kefasihan).

Analisis skor tes kemampuan berpikir kreatif siswa setelah dilatih memainkan kartu domica menghasilkan 6 siswa $(15,79 \%)$ sangat kreatif, 21 siswa $(55,26 \%) \quad$ kreatif, 8siswa $(21,05 \%)$ cukup kreatif, dan 3 siswa $(7,89 \%)$ kurang kreatif, sementara tidak ada satupun siswa yang tidak kreatif. Artinya $70 \%$ lebih menunjukkan siswa pada tingkat cukup kreatif atau kreatif setelah bermain kartu domica. Respon 
siswa adalah tanggapan siswa terhadap penggunaan kartu domica yang dikembangkan sesuai dengan pertanyaan yang dibuat. Hasil analisis data respons siswa terhadap kartu domica menunjukkan rata-rata total skor (\%) adalah 77,68 dengan kategori positif. Sehingga dapat dikatakan bahwa kartu domica memenuhi aspek keefektifan karena respon siswa positif dan lebih dari 70\% siswa cukup kreatif.

Media kartu domica pada fase ini disebut dengan prototipe final. Identifikasi proses dan hasil pada fase ini diperlukan untuk melakukan pertimbangan secara mendetail, apakah perlu merevisi kembali prototipe finalhasil ujicoba agar diperolehmedia yang relevan sesuai tujuan pengembangan. Susilana \& Riyana (2008), media yang baik adalah media yang dibuat melalui analisis komprehensif dengan memperhatikan aspek-aspek tertentu pembelajaran dan relevan bagi siswa sehingga dapat mengubah perilaku dan keterampilan siswa yang bermuara pada peningkatan mutu pembelajaran.
Pada uraian sebelumnya, uji coba penggunaan kartu domica pada fase ini telah memenuhi aspek kevalidan, kepraktisan, dan keefektifan untuk melatihkan kemampuan berpikir kreatif siswa sekolah dasar berdasarkan pengembangan model Plomp. Namun setelah dilakukan evaluasi dan refleksi kembali, siswa membutuhkan bahan ajar kartu domica, agar siswa lebih mudah memahami penggunaan kartu, serta aktivitas berpikir kreatif dan hasil berpikir kreatif siswa lebih berkembang. Dengan demikan, fase ujicoba sudah cukup dan akan ke tahapan berikutnya yakni fase Implementasi.

\section{Fase Implementasi}

Setelah menghasilkan prototipe final, kartu domica diterapkan dalam ruang lingkup sekolah lain. Penerapan ini dilakukan di kelas VI SDN Kalitengah 1 Tanggulangin Sidoarjo tahun ajaran 2017-2018 selama 4 kali pertemuan di bulan September. Hasil analisis data aktivitas berpikir kreatif siswa saat bermain kartu domica fase implementasi pada Tabel 2.

Tabel 2 Hasil Analisis Data Aktivitas Berpikir Kreatif Siswa

Pada Kartu Domica Berbasis Open Ended Fase Implementasi

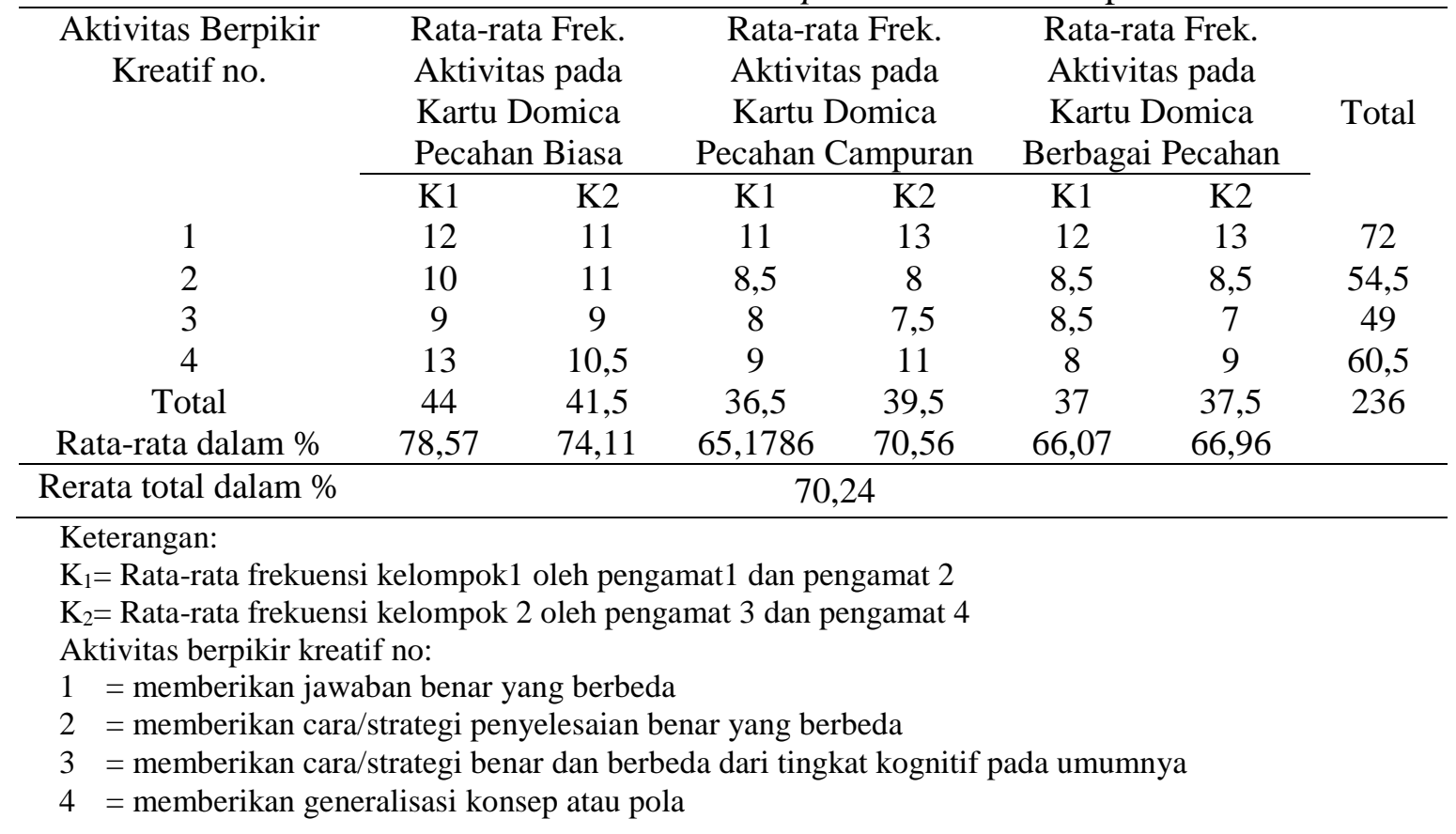


Rata-rata total aktivitas berpikir kreatif siswa pada fase implementasi adalah $70,24 \%$. Sementara aktivitas berpikir kreatif nomer 1 (kefasihan) sebesar 72 paling tinggi dan aktivitas berpikir kreatif nomer 3 (kebaharuan) sebesar 49 paling rendah diantara aktivitas berpikir kreatif yang lain. Hasil ini sama dengan aktivitas berpikir kreatif siswa pada tahap ujicoba. Namun sedikit berbeda pada aktivitas berpikir kreatif nomer 2 (fleksibilitas) sebesar 54,5 dan nomer 4 (elaborasi) sebesar 60,5 bahwa elaborasi menempati urutan ke dua, sementara fleksibilitas menempati urutan ke tiga. Hasil ini diduga karena pada fase implementasi siswa diberikan bahan ajar sehingga lebih mudah memainkan dan mengamati pola-pola kartu.

Pada tahap ujicoba dan implementasi menunjukkan bahwa kartu domica dapat memunculkan dan melatihkan kreativitas siswa dalam aspek kefasihan, fleksibiltas, elaborasi, dan kebaharuan. Sejalan dengan temuan penelitian ini bahwa pembelajaran matematika yang melibatkan open ended dapat meningkatkan kreativitas siswa sekolah dasar, penelitianpenelitian terdahuluoleh Saefudin (2012); Rudyanto (2016), Vale, dkk (2012); Ardiyanti, Suarjana, \& Garminah (2013) juga menemukan hal serupa bahwa kemampuan berpikir kreatif siswa akan berkembang salah satunya melalui pembelajaran yang menekankan aktivitas masalah terbuka (open ended).

Selain itu, kebaharuan menjadi aspek yang paling sulit untuk dilatihkan, sebaliknya kefasihan dan fleksibilitas menjadi aspek kreativitas yang lebih mudah untuk dilatihkan. Hal tersebut sesuai dengan pendapat Siswono (2008) bahwa dari ketiga aspek berpikir kreatif yakni kefasihan, fleksibiltas, kebaharuan. Aspek kreativitas yang paling menekankan pada berpikir divergen adalah kebaharuan, berikutnya secara berurutan adalah fleksibilitas dan kefasihan. Kebaharuan menempati posisi tertinggi karena merupakan ciri utama seseorang dikatakan kreatif.

Analisis skor tes kemampuan berpikir kreatif siswa setelah dilatih memainkan kartu domica menghasilkan sangat kreatif 7 orang $(17,5 \%), 15$ orang kreatif $(37,5 \%), 13$ orang cukup kreatif $(32,5 \%)$, dan 4 orang kurang kreatif (10\%), sementara tidak ada satupun siswa yang tidak kreatif.

Hasil analisis data respons siswa terhadap kartu domica pada fase implementasi diperoleh rata-rata total skor (\%) adalah 82,23 dalam kategori positif. Jadi hasil data respon siswa menggunakan kartu domica saat pembelajaran mendapat respon positif dan lebih dari $70 \%$ siswa berkategori minimal cukup kreatif pada tahap ujicoba dan implementasi. Sesuai dengan hasil tersebut, Murdiyanto \& Mahatama (2014) menyatakan media kartu domino model kartu pecahan biasa-persen merupakan salah satu media atau alat peraga yang dapat mewakili konsep maupun prinsip matematika yang abstrak sehingga proses belajar berlangsung menarik dan melibatkan partisipatif siswa secara aktif.

Temuan-temuan penelitian di atas menunjukkan kartu domica (domino pecahan) merupakan media yang baik untuk meningkatkan keterampilan berpikir kreativitas siswa sekolah dasar khususnya pada materi pecahan. Hal ini mendukung hasil-hasil penelitian sebelumnya terkait dengan media kartu domino. Hestuaji \& Riyadi (2013) hasil belajar siswa pada materi pecahan dasar menunjukkan hasil belajar yang lebih baik dengan menggunakan kartu domino dibandingkan menggunakan media gambar diam. Dalam Newsletter 
PRIORITASkuen sebuah media komunikasi pendidikan dasar di Jawa Barat, Herawati (2014) yang meraih penghargaan inovasi belajar menyatakan media berupa kartu domino efektif meningkatkan pemahaman materi siswa pada mata pelajaran matematika.

\section{KESIMPULAN DAN SARAN}

Uji coba dan Implementasi berdasarkan model Plomp dapat disimpulkan bahwa pengembangan kartu domica berbasis open ended untuk meningkatkan kreativitas siswa sekolah dasar menghasilkan dua set kartu domica sub materi pecahan biasa dan pecahan campuran, serta satu set kartu domica yang terdiri dari seluruh sub materi pecahan (pecahan biasa, persen, dan desimal) yang masing-masing berisi 66 kartu.

Kartu domica berbasis open ended hasil uji coba berkualitas baik karena telah memenuhi aspek kevalidan, kepraktisan, dan keefektivan untuk melatihkan kreativitas siswa dalam aspek kefasihan, fleksibiltas, elaborasi, dan kebaharuan. Hal ini dapat dilihat dari (1) Kartu domica dan Tes Berpikir Kreatif (TBK) valid serta lembar observasi dan angket respon sangat valid berdasarkan penilaian validator. (2) Kartu domica praktis berdasarkan penilaian validator karena dilakukan sedikit revisi sebelum ujicoba dan aktivitas berpikir kreatif siswa menggunakan kartu domica dalam kategori praktis pada fase ujicoba $70,08 \%$ dan fase implementasi 70,24\%.

(3) Kartu domica efektif berdasarkan respon positif siswa terhadap kartu domica pada fase ujicoba sebesar $77,68 \%$ dan fase implementasi $82,23 \%$. Sementara tingkat berpikir kreatif siswa saatfase ujicoba dan implementasi minimal berkategori cukup kreatif sebesar minimal $70 \%$ dengan rincian pada fase uji coba 6 siswa $(15,79 \%)$ sangat kreatif, 21 siswa $(55,26 \%)$ kreatif, 8 siswa $(21,05 \%)$ cukup kreatif. Sementara pada fase implementasi 7 siswa $(17,5 \%)$ sangat kreatif, 15 siswa $(37,5 \%)$ kreatif, 13 siswa $(32,5 \%)$ cukup kreatif.

Adapun saran dalam penelitian meliputi (1) Kartu Domica berbasis open ended yang dihasilkan dalam penelitian ini sebaiknya digunakan sebagai media alternatif untuk melatihkan atau meningkatkan kreativitas siswa sekolah dasar. (2) Kartu domica dimungkinkan digunakan oleh siswa pada tingkatan yang lebih tinggi untuk melatih kefasihan, fleksibitas dan memunculkan kebaruan siswa dalam menjawab soal-soal matematika khususnya pada materi pecahan.

\section{DAFTAR PUSTAKA}

Apino, E., \& Retnawati, H. 2017. Developing Instructional Design to Improve Mathematical Higher Order Thinking Skills of Students. In Journal of Physics: Conference Series. IOP Publishing. Vol. 812, No. 1, p. 012100.

Ardiyanti, N. P. R., Suarjana, I. M., \& Garminah, N. N. 2013. Pengaruh Model Pembelajaran Matematika Berorientasi Open-Ended Problem Terhadap Kemampuan Berpikir Kreatif Siswa Pada Mata Pelajaran Matematika Kelas IV SD. MIMBAR PGSD. Vol. 1, No. 1, Hal.732-742.

BNSP. 2016. Lampiran Peraturan Menteri Pendidikan dan Kebudayaan Nomor 20 Tahun 2016 Tentang Standar Kompetensi Lulusan Pendidikan Dasar dan Menengah. Jakarta: Depdiknas. 
Hestuaji, Y., \& WA, S. 2013. Pengaruh Media Kartu Domino terhadap Pemahaman Konsep Pecahan. Jurnal Didaktika Dwija Indria. Vol. 3, No. 1, Hal. 1-6.

Khabibah, S. 2006. Pengembangan Model Pembelajaran Matematika dengan Soal Terbuka untuk Meningkatkan Kreativitas Siswa Sekolah Dasar. Disertasi Universitas Negeri Surabaya.

Kristiyono, H. 2008. Mahir Perkalian dan Pembagian Bilangan Dasar Melalui Metode Permainan Kartu. Jurnal Pendidikan Penabur. Vol. 7, No. 10, Hal.110.

Mahmudi, A. 2009. Mengembangkan Kemampuan Berpikir Kreatif Siswa Melalui Pembelajaran Topik Pecahan. Makalah Disampaikan Pada Seminar Nasional Aljabar, Pengajaran, dan Terapannya. Yogyakarta. Hal. 179-192.

Murdiyanto, T., \& Mahatama, Y. 2014. Pengembangan Alat Peraga Matematika Untuk Meningkatkan Minat dan Motivasi Belajar Matematika Siswa Sekolah Dasar. Jurnal Sarwahita. Vol. 11, No. 1, Hal.38-43.

Newsletter PRIORITASkuen. 2014. Media komunikasi untuk mendorong pembaharuan, menciptakan peluang kemajuan, dan membuka akses pendidikan dasar yang berkualitas. 2014. Jawa Barat: USAID PRIORITAS. No. Edisi 8, Bulan JuliSeptember, Hal. 8.

Nieveen, N., Gustafson, K., Branch, R. M., \& van den Akker, J. 1999. Design approaches and tools in education and training. Dordrecht: ICO Cluwer academic publisher.

Plomp, T. 1997. Educational and training system design. Enschede: University of Twente.

Ristiani, R. 2014. Identifikasi Tingkat Berpikir Kreatif Siswa dalam Memecahkan Masalah Matematika melalui Tipe Soal Open Ended pada Materi Pecahan Kelas $V$ di SDN Tegalrejo 02 Salatiga. Disertasi: Program Studi Pendidikan Matematika FKIP-UKSW.

Rochmad, R. 2012. Desain Model Pengembangan Perangkat Pembelajaran Matematika. Jurnal Kreano. Vol. 3, No. 1, Hal. 59-72.

Rudyanto, H. E. 2016. Pengembangan Kreativitas Siswa Sekolah Dasar Melalui Pembelajaran Matematika Open-Ended. Premiere

Educandum (Jurnal Pendidikan Dasar dan Pembelajaran). Vol. 3, No. 2, Hal. 184-192.

Saefudin, A. A. 2012 Pengembangan Kemampuan Berpikir Kreatif Siswa dalam Pembelajaran Matematika dengan Pendekatan Pendidikan Matematika Realistik Indonesia (PMRI). Jurnal Al-Bidayah (Jurnal Pendidikan Dasar Islam). Vol. 4, No. 1. Hal. 37-48.

Sanjaya, Wina. 2013. Strategi Pembelajaran: Berorientasi Standar Proses Pendidikan. Jakarta: Kencana Prenadamedia Group.

Siswono, T. Y. E. 2008. Model pembelajaran matematika berbasis pengajuan dan 
ISSN 2089-8703 (Print) Vol. 6, No. 2 (2017)

ISSN 2442-5419 (Online)

pemecahan masalah untuk meningkatkan kemampuan berpikir kreatif. Surabaya: Unesa University.

Sitanggang, A. 2013. Alat Peraga Matematika Sederhana Untuk Sekolah Dasar. Medan: Lembaga Penjaminan Mutu Pendidikan Sumatera Utara.

Sugiyono. 2013. Metode Penelitian Pendidikan (Pendekatan Kuantitatif, Kualitatif, dan $R \& D)$. Bandung: Alfabeta.

Susilana, R., Si, M., \& Riyana, C. 2008.Media Pembelajaran: Hakikat, Pengembangan, Pemanfaatan, dan Penilaian. Surakarta: CV. Wacana Prima.

Vale, I., Pimentel, T., Cabrita, I., Barbosa, A., \& Fonseca, L. 2012. Pattern problem solving tasks as a mean to foster creativity in mathematics. Proceedings of the 36th Conference of the International Group for the Psychology of Mathematics Educatio. Vol. 4, pp. 171-178. 